\title{
Pectin Microspheres: Synthesis Methods, Properties, and Their Multidisciplinary Applications
}

\author{
Keila Gutierrez-Alvarado ${ }^{1, *}$, Randall Chacón-Cerdas ${ }^{1}$ (D) and Ricardo Starbird-Perez ${ }^{2}$ (D) \\ 1 Instituto Tecnológico de Costa Rica, Centro de Investigación en Biotecnología, Avenida 14, Calle 15, \\ Cartago 30101, Provincia de Cartago, Costa Rica; rchacon@itcr.ac.cr \\ 2 Instituto Tecnológico de Costa Rica, Escuela de Química, Avenida 14, Calle 15, \\ Cartago 30101, Provincia de Cartago, Costa Rica; rstarbird@itcr.ac.cr \\ * Correspondence: k.gutierrez@estudiantec.cr; Tel.:+506-8937-3732
}

check for

updates

Citation: Gutierrez-Alvarado, K.;

Chacón-Cerdas, R.; Starbird-Perez, R Pectin Microspheres: Synthesis Methods, Properties, and Their Multidisciplinary Applications. Chemistry 2022, 4, 121-136. https: / /doi.org/10.3390/ chemistry4010011

Academic Editors: Nobuo Kimizuka and Pietro Russo

Received: 4 January 2022

Accepted: 22 February 2022

Published: 1 March 2022

Publisher's Note: MDPI stays neutral with regard to jurisdictional claims in published maps and institutional affiliations.

Copyright: () 2022 by the authors Licensee MDPI, Basel, Switzerland. This article is an open access article distributed under the terms and conditions of the Creative Commons Attribution (CC BY) license (https:// creativecommons.org/licenses/by/ $4.0 /)$.

\begin{abstract}
There is great contemporary interest in using cleaner technologies through green chemistry and utilizing biopolymers as raw material. Pectin is found on plant cell walls, and it is commonly extracted from fruit shells, mostly apples or citrus fruits. Pectin has applications in many areas of commercial relevance; for this reason, it is possible to find available information about novel methods to transform pectin and pursuing enhanced features, with the structuring of biopolymer microspheres being highly cited to enhance its activity. The structuring of polymers is a technique that has been growing in recent decades, due to its potential for diverse applications in various fields of science and technology. Several techniques are used for the synthesis of microspheres, such as ionotropic gelation, extrusion, aerosol drying, or emulsions, with the latter being the most commonly used method based on its reproducibility and simplicity. The most cited applications are in drug delivery, especially for the treatment of colon diseases and digestive-tract-related issues. In the industrial field, it is used for protecting encapsulated compounds; moreover, the environmental applications mainly include the bioremediation of toxic substances. However, there are still many possibilities for expanding the use of this biopolymer in the environmental field.
\end{abstract}

Keywords: biopolymer; pectin; microspheres; structuring methods; delivery of substances; health; industry; environment

\section{Introduction}

Biopolymers are found in abundance in nature; they have desirable physicochemical characteristics for covalent or ionic structuring, and they are biodegradable, usually obtained from wastes from agro-industrial processes. Thus, they are a value-added side product, which reduces contamination through inappropriate disposal and accumulation, in contrast to synthetic polymers, which consume petroleum-based resources and are non-biodegradable [1,2]. Therefore, finding alternative uses for these biopolymers has been researched and applied [1]. Following this idea, pectin, a promising polysaccharide, has been used in the structuring of spheres due to its gelling capacity, low toxicity, and biocompatibility [3]. It is a biopolymer found naturally in plants, formed of D-polygalacturonic acid bound by $\alpha$-1,4-glucosidic bonds.

In the last two decades, the structuring of polymers has been growing as a technique that has the potential to improve many fields of science and technology, including manufacturing bioengineering, electronics, biotechnology, and medicine [4-8]. This technique has important environmental impacts, due to the low costs of the formulation of new materials, with multiple functions, and it could bring revolutionary innovations to all of the fields mentioned before [9].

Due to the scale at which such polymers are structured/modified, it is necessary to use micro- and nanotechnology methods. Among them, polymeric microspheres have been 
one of the most widely used options for the smart delivery of compounds because they have the ability to ensure a controlled and gradual delivery, in addition to being mostly biocompatible and non-toxic [10]. However, the synthesis methods do not always meet the requirements of green chemistry, and some of the manufacturing process byproducts pollute the environment or are toxic for humans, limiting their mass production [11]. For this reason, certain research in this area has recognized the need to implement sustainability in nanotechnology $[12,13]$. Consequently, attempts have been made to migrate to techniques that generate fewer toxic products and side products, including the use of biopolymers such as chitosan and pectin in sphere manufacturing [1].

The objective of this review is to summarize the main synthesis methods that have been used for the structuring of pectin microspheres. Comparing their respective advantages with each other, the applications in fields such as drug delivery, multidisciplinary industrial applications, and the prospects for further research show evidence of the positive impact of microsphere structuring in such areas by means of pectin's potential as a unique raw material.

\section{Pectin: Functions, Structure and Characteristics}

In plants, pectin is located in the cell walls—specifically, in the middle lamella—and it appears in the early stages of the formation of the primary (mainly) and secondary cell walls [14]. In dicotyledons, the primary wall is $35 \%$ pectin, $30 \%$ cellulose, $30 \%$ hemicellulose, and approximately $5 \%$ proteins [15]. It is mainly extracted from some fruits, such as citrus fruits and apples, although pectin is also present in monocotyledons such as pastures. It is usually given different uses for its gelling capacity [16].

Pectin participates in important biological functions, such as in ensuring cell wall porosity, influencing surface tension, $\mathrm{pH}$ regulation, balance, and ion transport through the wall [17]. In the cell wall, pectin provides hardness and creates a barrier against the environment; in addition, pectin participates in the signaling cascade that detects degradation when the wall is under attack from a pathogen [18].

Its ability to induce defense responses in plants against pathogens has been extensively researched and is widely known, because it is an elicitor defense molecule [19-21]. Pectin contributes to the production and accumulation of phytoalexins and reactive oxygen species in the event of an attack by a pathogen on the plant $[17,22]$. Subsequently, it also helps in the creation of peptides and defensive proteins $[17,23,24]$.

The most well-known chemical structure of pectin is mainly that of the primary walls because pectin of the secondary walls has to be extracted with chemical or enzyme methods that changes their structure. Therefore, it is known that $65 \%$ of pectin is a homogalacturonan (HG) polymer of galacturonic acid (GalA) bound in s-1,4 [25]. It has been found acetylated to a lower grade in positions O-2 and O-3, and methylsterified to a higher degree in O-6. If the HG is found in O-3 or apiosylated in O-2 and/or O-3, it forms xylogalacturonan (XGA) and apiogalacturonan (AGA) [26,27].

Rhamnogalacturonan II (RG-II) makes up 10\% of pectin and plays an important role in plant growth and development. This is an HG backbone replaced with chains of an octasaccharide and a nonasaccharide attached to the O-2 through residues of s-d-celosyl (Apif) and two chains of disaccharides attached to the O-3. Rhamnogalacturonan I (RG-I) constitutes $20-35 \%$ of pectin and is a disaccharide of joined repetitions of [4-d-GalA- $(1,2)-1-$ Rha-1]n and GalA residues which are acetylated in O-2 or O-3. $[25,28]$ Figure 1 shows the typical molecular structure of pectin.

In addition, pectin can be classified depending on its degree of esterification in low levels of methoxyl $(<50)$ or high levels of methoxyl $(>50)$, depending on the relationship between methoxylated and free groups [29]. This characteristic gives high-level methoxyl pectin the ability to form gels in the presence of high sugar concentrations, whereas low methoxyl pectin can form gels in the presence of divalent cations [30]. Thus, these are very useful characteristics for the food, agricultural, or medical industries [31,32]. 


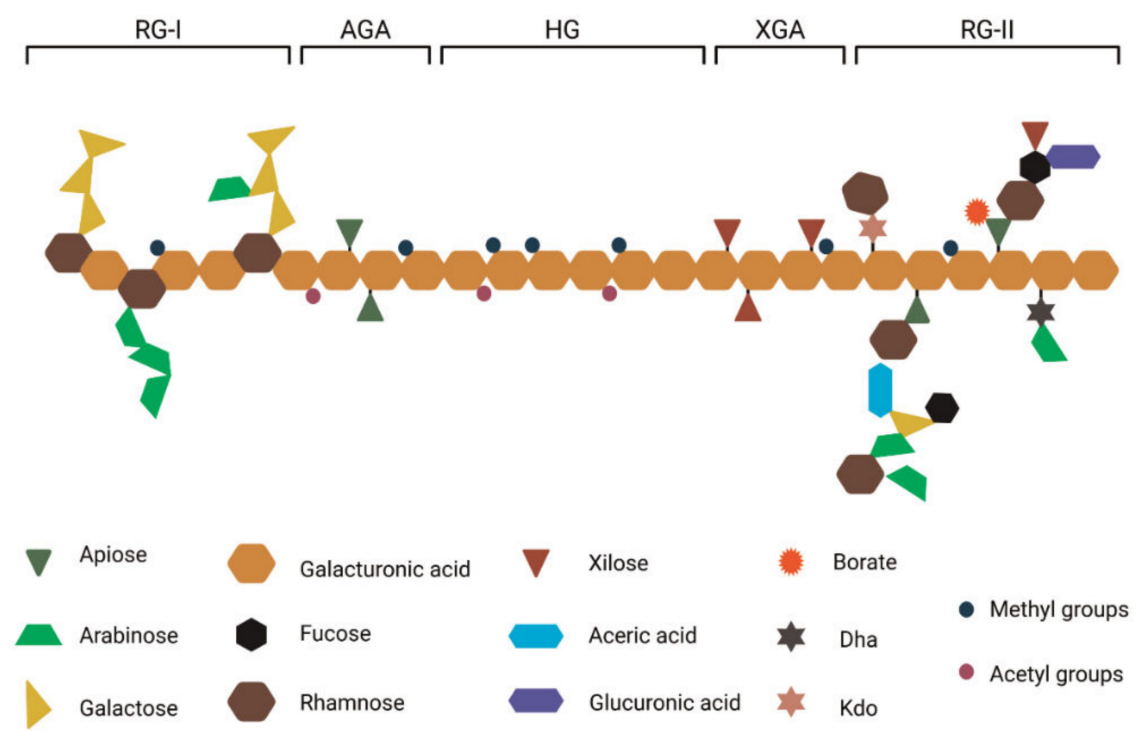

Dha $=3$ deoxy-lyxo-2-heptulosaric acid, Kdo= 3-deoxy-manno-2-octulosonic acid.

Figure 1. Molecular structure of pectin.

In the food industry, pectin (especially that extracted from citrus fruits and apples) is very important because it is used as a gelling agent, stabilizer, and thickener in products such as jellies, yogurt, milk, and ice cream [30]. It is also known for its medicinal use in combination with plant extracts for the treatment of diarrhea; pectin is associated with blocking the adhesion of pathogenic microorganisms to the intestinal mucosa, as well as immunoregulatory effects altering ileal microbial activity, thus serving to lower blood cholesterol and decrease glucose absorption in the sera of diabetic and obese patients [33-36].

Those diverse applications are given by modifications of its chemical characteristics. For example, through alkylation, it is possible to increase pectin's hydrophobicity and change its viscosity and emulsifying capacity [37]. With sulfation, the pectin anticoagulant activity is improved [38] and oxidation results in the faster degradation of pectin and reactive groups, which helps in the controlled drug-delivery [39]. Alternatively, through depolymerization, oligosaccharides are generated, which can then be used in antioxidant, antibacterial, prebiotic processes [30].

\section{Methods for the Synthesis of Microspheres}

The structuring methods to produce microspheres are summarized in this section; the most common methodologies reported by several authors correspond to emulsion and coacervation, ionotropic gelation, spray drying, hydrothermal synthesis and extrusion.

\subsection{Emulsion and Coacervation}

Emulsions are a mixture of two immiscible liquids, basically consisting of droplets of one liquid dispersed in the other, thus generating an unstable system. It is for this reason that an emulsifier or surfactant is added to the emulsions, to diminish the associated free energy and to stabilize it kinetically $[40,41]$. This is one of the most common methods for structuring microspheres due to its simplicity, low cost, and reproducibility [42]. There are several types of emulsions such as ethanol in oil [43], water in oil [44] or oil in water [45,46] and their use depends on the materials to be structured and the desired final application.

Polymers are molecules whose size falls within the colloidal range, and they affect the droplet size distribution in the emulsion [47]. The fabrication of microspheres by coacervation consists of forming a phase called coacervate by separating the phases of the initial hydrocolloids of the solution. Coacervation is divided into two types: simple and complex. In simple coacervation, a separation forms two phases, one of which is saturated 
in the polymer that is in solution, and the other which is in equilibrium but depleted from the polymer [48]. In contrast, complex coacervation consists of a mixture of two immiscible liquids with each other, where a concentrated interface is formed in polymers of opposite charge. This interface is called coacervate, generated by weak interactions such as hydrogen bonds, electrostatic, hydrophobic, or van der Waals forces [49,50]. Biopolymers, such as polysaccharides, are widely employed as functional ingredients in emulsion systems. Specifically, the structuring of pectin microspheres is carried out by coacervation. This coacervate will be positioned around the active ingredient found in the emulsified solution.

Several studies have been carried out with this method, covering a wide range of applications, from microspheres for controlled drug-delivery, such as acetaminophen [51], to the encapsulation of oils for the food industry [52]. The advantages that have been observed with this method are an increased resistance to mechanical stress or temperature and the subsequent controlled delivery of substances inside the microspheres [53].

\subsection{Ionotropic Gelation}

Ionotropic gelation is based on the principle that polymers can be crosslinked when they are in the presence of an electrostatic interaction between them and oppositely charged crosslinkers, considering the $\mathrm{pH}$ and the concentration of the polymers [54,55].

One of the main reasons why this method is used for microsphere structuring is because the degree of crosslinking and the polymer concentration can be modified, which makes it very useful in the field of controlled drug delivery. Moreover, due to ion interactions, a dense and strong hydrogel network can be created for multiple investigations [56].

For pectin microsphere synthesis, this technique is often used in conjunction with crosslinking agents such as calcium chloride or chlorhexidine (an antimicrobial agent), because electrostatic bonds are formed between the negatively charged carboxyl groups of pectin and the positively charged crosslinkers [57,58].

Research has been carried out using the ionotropic gelation method with pectin microspheres to encapsulate violet crystal, ciprofloxacin, polyphenols, and $\beta$-carotenes of Taraxacum officinale [59-61]. All of this research has applications for human health.

\subsection{Spray Drying}

Spray/aerosol drying is based on the principle that a solution (usually aqueous) can be turned into a powder. First, the solution is atomized and mixed with a drying gas, the solvent is evaporated from the solution, and the powder obtained is separated from the drying gas $[62,63]$. One of the main reasons supporting the use of this method in structuring microspheres is because of its low cost, reproducibility, and simplicity [64]. In addition, the characteristics of the microspheres can be optimized, heat-sensitive materials can be encapsulated, and their microbiological quality is ensured [64,65].

Spray drying is one of the most commonly used techniques for drug encapsulation; this process helps with the controlled release of the composite [64]. Research on pectin microspheres has focused on this feature too; for example, in the encapsulation of drugs such as albendazole, folic acid, and melatonin [66-68].

\subsection{Hydrothermal Synthesis}

Hydrothermal synthesis is one of the most commonly used alternatives methods to fabricate nanomaterials. The creation of particles involves hydrolysis and condensation in a medium (normally water), and a high temperature and pressure. At an ambient temperature, the medium is mixed with water which contains composites for the microspheres. Moreover, the medium provides an excellent environment for the formation of the particles and stabilization of the desired products, avoiding the formation of undesirable products $[69,70]$.

Some of the advantages of this method are that it is environmentally friendly, low cost, involves low temperature and the equipment that is needed is simple and easy to 
use. It is also inexpensive and has excellent control of the particle size, structure and morphology $[70,71]$.

Research has been done using the hydrothermal method for make pectin microparticles with the capacity of adsorption of methylene blue or pectin $/ \mathrm{GeO}_{2}$ microspheres that have antibacterial activities and also sustainable pectin/carbon microspheres for in vivo bioimaging [72-74].

\subsection{Extrusion}

Microparticles are formed through extrusion by using an encapsulator with a nozzle [75]. Consequently, a solution travels through the extruder (such as a needle), and it is deposited it in a bath gelling solution [76,77].

This method of synthesis has variations such as co-extrusion and extrusion-spheronization. In co-extrusion, the main difference is that a concentric nozzle vibration system is used, which involves jet-cutting the poured solution into droplets [78]. For extrusion-spheronization, a dry powder is mixed in a liquid, passed through an extruder, broken out, converted to pellets in a spheronization step, and dried out [79].

Similar to other methods listed in this review, the use of the extrusion technique as a synthesis method for microparticles of pectin has many advantages, such as high drug loading capacity, high productivity, low hygroscopicity of the microparticles, and high resistance to gastrointestinal conditions [76,80]. Moreover, it allows the use of two liquids to make microspheres with a very different melting point and forming high-quality bonds between them [81]. Extrusion methods are very useful in the food industry because they reduce the oxidation of lipids and bioactive compounds, and do not use organic solvents $[75,76,78]$.

Extrusion is the encapsulating method for kenaf seed oil in pectin microspheres [75], as well as in pectin/alginate structuring for the controlled release of polyphenols from papaya [76] and folic acid [82] to protect Lactobacillus acidophilius in gastrointestinal fluids [78] and make pectin-coated nanoliposomes [83], among others.

\section{Pectin Microsphere Applications}

This section prevents different areas in which pectin microspheres have been used; this specific review is mainly concerned with drug delivery, and other less frequent but diverse multidisciplinary industrial applications.

\subsection{Drug Delivery}

The implementation of microspheres of pectin in drug delivery applications has contributed to the development of new treatments with smart drug release. In Table 1, multiple investigations regarding the subject are compiled, focusing on the main characteristics of the pectin, the resulting microspheres, and the relevant details of their application (this being the field with the most information generated).

Table 1. Characteristics of synthesized pectin microspheres for drug delivery applications.

\begin{tabular}{|c|c|c|c|c|c|}
\hline Sphere Type & Synthesis Method & Pectin Properties & Characteristics of the Spheres & Drug & Application \\
\hline $\begin{array}{l}\text { Shellac-coated } \\
\text { pectin } \\
\text { microspheres }\end{array}$ & $\begin{array}{l}\text { W/O emulsification } \\
\text { and linking with } \mathrm{CaCl}^{2+} \\
\text { solvent evaporation }\end{array}$ & $\mathrm{N} / \mathrm{A}$ & $\begin{array}{c}\text { Diameter of } 28-35 \mu \mathrm{m} \\
\text { Encapsulation efficiency of } \\
73-82 \% \\
\text { pH-dependent release; faster } \\
\text { with an acidic pH and slower } \\
\text { with a basic pH }\end{array}$ & Vincristine sulfate & $\begin{array}{l}\text { Colon cancer treatment } \\
\text { by controlled drug } \\
\text { release [84]. }\end{array}$ \\
\hline $\begin{array}{c}\text { Pectin } \\
\text { microspheres }\end{array}$ & $\begin{array}{l}\text { W/O emulsification + } \\
\text { solvent evaporation }\end{array}$ & $\mathrm{N} / \mathrm{A}$ & $\begin{array}{c}\text { Diameter of } 34-71 \mu \mathrm{m} \\
\text { Yield of } 78-88 \% \\
\text { Drug content of } 15-33 \% \\
\text { Encapsulation efficiency of } \\
26-67 \% \\
\text { 95-98\% of drug release in } 9 \mathrm{~h} \text { at a } \\
\text { pH of } 6.8\end{array}$ & $\begin{array}{l}\text { Metformin } \\
\text { Hydrochloride }\end{array}$ & $\begin{array}{l}\text { Selective oral drug } \\
\text { release for diabetes } \\
\text { mellitus type II [85]. }\end{array}$ \\
\hline
\end{tabular}


Table 1. Cont.

\begin{tabular}{|c|c|c|c|c|c|}
\hline $\begin{array}{l}\text { Pectin }+\mathrm{Ag}_{3} \mathrm{PO}_{4} \\
\text { mesoporous hybrid } \\
\text { microspheres }\end{array}$ & Ionotropic gelation & $\begin{array}{c}\text { Highly methoxylated } \\
\text { (HMP) } \\
\text { Esterification degree } \\
\text { of } 74 \% \\
\text { Average of } \\
1.60 \times 10^{5} \mathrm{Da}\end{array}$ & $\begin{array}{c}\text { Diameter of } 1.3-1.5 \mu \mathrm{m} \\
\text { Yield of } 90 \%\end{array}$ & Levofloxacin & $\begin{array}{c}\text { Antimicrobial particles } \\
\text { for controlled drug } \\
\text { release [86]. }\end{array}$ \\
\hline $\begin{array}{l}\text { Pectin } \\
\text { microspheres }\end{array}$ & $\begin{array}{l}\text { Ionotropic gelation with } \\
\mathrm{CaCl}_{2}+\text { linking with } \\
\text { polyethyleneimine }\end{array}$ & $\begin{array}{c}\text { Amidated of low } \\
\text { methoxylated OG } 175 \mathrm{C} \\
\text { Esterification degree of } \\
22-28 \% \\
\text { Amidation degree of } \\
19-23 \%\end{array}$ & $\begin{array}{l}\text { Average diameter of } 1010 \mu \mathrm{m} \\
\text { Encapsulation efficiency of } 80 \% \\
\text { Expansion ratio at } 1.5 \mathrm{~h} \text { of } 7.9 \\
\text { Disintegration time of } 7 \mathrm{~h}+ \\
86 \% \text { of their biological activity } \\
\text { remains after } 5 \mathrm{~h} \text { in a basic } \\
\text { environment }(\mathrm{pH} \text { of } 6.0)\end{array}$ & B-lactamase & $\begin{array}{l}\text { Controlled b-lactamase } \\
\text { release in colon to } \\
\text { reduce bacterial } \\
\text { antibiotic } \\
\text { resistance [87]. }\end{array}$ \\
\hline $\begin{array}{l}\text { Pectin/chitosan } \\
\text { hybrid } \\
\text { microspheres }\end{array}$ & Aerosol drying & $\begin{array}{c}\text { Esterification degree of } \\
70-75 \% \\
30-100 \mathrm{~K} \mathrm{Mr}\end{array}$ & $\begin{array}{c}\text { Average of diameter of } 3 \mu \mathrm{m} \\
16-32 \% \text { of drug content } \\
\text { Expansion by hydration of } \\
100-180 \% \\
\text { pH-dependent release } \\
70-80 \% \text { of drug release in } 10 \mathrm{~h} \text { at } \\
\text { a pH of } 5.5\end{array}$ & Vancomycin & $\begin{array}{l}\text { Controlled antibiotic } \\
\text { release for colon } \\
\text { infections [88]. }\end{array}$ \\
\hline $\begin{array}{l}\text { Algin/pectinate } \\
\text { hybrid } \\
\text { microspheres }\end{array}$ & $\begin{array}{l}\text { Ionotropic gelation } \\
\text { with } \mathrm{CaCl}_{2}\end{array}$ & $\begin{array}{c}\text { Highly } \\
\text { methoxylated (HMP) } \\
\text { Average of } \\
1.76 \times 10^{6} \mathrm{Da} \mathrm{Mr}\end{array}$ & $\begin{array}{c}\text { Diameter of } 740-810 \mu \mathrm{m} \\
\text { Yield of } 9 \% \\
\text { Encapsulation efficiency of } \\
84-96 \% \\
\text { pH-dependent release; faster } \\
\text { with a basic } \mathrm{pH} \text { and slower with } \\
\text { an acidic } \mathrm{pH} \\
90 \% \text { of drug release in } 12 \mathrm{~h} \text { at a } \\
\text { pH of } 6.8\end{array}$ & Aceclofenac & $\begin{array}{l}\text { Controlled oral } \\
\text { anti-inflammatory } \\
\text { drugs [89]. }\end{array}$ \\
\hline $\begin{array}{l}\text { Calcium pectinate } \\
\text { microspheres }\end{array}$ & $\begin{array}{l}\text { W/O emulsification } \\
\text { and linking with } \mathrm{CaCl}_{2}\end{array}$ & $\begin{array}{l}\text { Low methoxylated } \\
\text { Esterification degree } \\
\text { of } 6 \%\end{array}$ & $\begin{array}{c}\text { Diameter of } 20-32 \mu \mathrm{m} \\
\text { Drug content of } 20 \% \\
\text { Encapsulation efficiency of } 74 \% \\
\text { Expansion ratio until constant } \\
\text { weight of } 0.3-1.3 \% \\
\text { pH-dependent release; more with } \\
\text { a basic pH and less with an } \\
\text { acidic } \mathrm{pH} \\
20 \% \text { of drug release in } 24 \mathrm{~h} \text { at a } \\
\text { pH of } 7.0\end{array}$ & Methotrexate & $\begin{array}{c}\text { Colon cancer treatment } \\
\text { by controlled drug } \\
\text { release [90]. }\end{array}$ \\
\hline $\begin{array}{c}\mathrm{TiO}_{2} / \mathrm{Fe}_{3} \mathrm{O}_{4} / \text { pectin } \\
\text { hybrid } \\
\text { microspheres }\end{array}$ & $\begin{array}{l}\text { W/O emulsification } \\
\text { and covalent linking } \\
\text { induced by ultrasound }\end{array}$ & $\begin{array}{l}\geq 74.0 \% \\
\text { galacturonic acid }\end{array}$ & $\begin{array}{c}\text { Diameter of } 0.68 \mu \mathrm{m} \\
\text { Zeta potential of }-4.87 \mathrm{mV} \\
82 \% \text { of drug content } \\
7 \% \text { of drug release in } 5 \mathrm{~h} \text { at a } \mathrm{pH} \\
\text { of } 2.0\end{array}$ & Amoxicillin & $\begin{array}{l}\text { Slow and maintained, } \\
\text { controlled antibiotic } \\
\text { release in the } \\
\text { stomach [91]. }\end{array}$ \\
\hline $\begin{array}{l}\text { Pectin } \\
\text { microspheres }\end{array}$ & $\begin{array}{l}\text { Linking with zinc } \\
\text { acetate and } \\
\text { glutaraldehyde }\end{array}$ & $\begin{array}{c}\text { Esterification degree } \\
\text { of } 28 \% \\
\text { Amidation degree } \\
\text { of } 20 \%\end{array}$ & $\begin{array}{c}\text { Diameter of } 898-1053 \mu \mathrm{m} \\
\text { Humidity content of } 8-13 \% \\
\text { Encapsulation efficiency of } \\
\text { 93-98\% } \\
\text { pH-dependent release; faster } \\
\text { with a basic pH (6.8) and slower } \\
\text { with an acidic pH (1.2) }\end{array}$ & Resveratrol & $\begin{array}{l}\text { Controlled drug release } \\
\text { for colon cancer } \\
\text { treatment [92]. }\end{array}$ \\
\hline $\begin{array}{l}\text { Dexamethasone/algi } \\
\text { nanoparticles } \\
\text { encapsulated by } \\
\text { pectin } \\
\text { microspheres }\end{array}$ & Aerosol drying & $\begin{array}{c}\text { Amidated of low } \\
\text { methyl esterification } \\
\text { CF025 } \\
\text { Esterification degree of } \\
\text { 23-28\% } \\
\text { Amidation degree of } \\
\text { 22-25\% }\end{array}$ & $\begin{array}{c}\text { Diameter of } 2.76 \mu \mathrm{m} \\
\text { Zeta potential of }-36 \mathrm{mV} \\
\text { Drug content of } 3 \% \\
\text { Yield of } 45-70 \%\end{array}$ & Dexamethasone & $\begin{array}{l}\text { Controlled release of } \\
\text { mucoadhesive drug in } \\
\text { nasal solution [65]. }\end{array}$ \\
\hline $\begin{array}{l}\text { Pectin } \\
\text { microspheres }\end{array}$ & $\begin{array}{l}\text { Ionotropic gelation } \\
\text { with } \mathrm{CaCl}_{2}\end{array}$ & $\begin{array}{c}\text { Low proportion of } \\
\text { amidated } \\
\text { methoxylation } \\
\text { Molecular weight of } \\
228,000 \mathrm{Da} \\
\text { Esterification degree } \\
\text { of } 30 \% \\
\text { Amidation degree } \\
\text { of } 19 \%\end{array}$ & $\begin{array}{c}\text { Diameter of } 280 \mu \mathrm{m} \\
\text { Polydispersity index of } 0.69 \\
\text { Drug content of } 4 \% \\
\text { Encapsulation efficiency of } 77 \% \\
\text { Slow and lengthy release at pH of } \\
7.5 \text {, approximately } 62 \% \text { in } 45 \text { days }\end{array}$ & Ibuprofen & $\begin{array}{l}\text { Macroporous } \\
\text { structuring in bone } \\
\text { implant material and } \\
\text { controlled drug } \\
\text { release [93]. }\end{array}$ \\
\hline $\begin{array}{l}\text { Algin/pectinate } \\
\text { hybrid } \\
\text { microspheres }\end{array}$ & $\begin{array}{l}\text { Ionotropic gelation } \\
\text { with } \mathrm{CaCl}_{2}\end{array}$ & $\begin{array}{c}\text { Highly methoxylated } \\
\text { (HMP) } \\
\text { Esterification degree } \\
\text { of } 74 \% \\
\text { Average MW of } 160 \mathrm{kDa}\end{array}$ & $\begin{array}{l}\text { Encapsulation efficiency of } 47 \% \\
\quad \text { Expansion by hydration of } \\
\quad 190-300 \% \\
\text { Slow release at gastric pH of } 1.2 \\
\text { and fast release at a basic pH (7.4) }\end{array}$ & Ciprofloxacin & $\begin{array}{l}\text { Controlled antibiotic } \\
\text { release in the digestive } \\
\text { tract and degradation } \\
\text { protection [94]. }\end{array}$ \\
\hline $\begin{array}{l}\text { Pectin } \\
\text { microspheres }\end{array}$ & $\begin{array}{l}\text { Aerosol drying and } \\
\text { linking with } \mathrm{CaCl}_{2}\end{array}$ & $\begin{array}{l}\text { Low methoxylated } \\
\text { amidation } \\
\text { Esterification degree } \\
\text { of } 9 \%\end{array}$ & $\begin{array}{l}\text { Encapsulation efficiency of } 13 \% \\
\text { Drug content of } 5 \% \\
\text { Slow release at } 1.2 \mathrm{pH} \text { in } 24 \mathrm{~h} \\
\text { of } 18 \% \\
\text { Fast release at } 7.4 \mathrm{pH}\end{array}$ & Indomethacin & $\begin{array}{c}\text { Controlled drug release } \\
\text { for gastrointestinal } \\
\text { disease treatment [95]. }\end{array}$ \\
\hline
\end{tabular}


Table 1. Cont.

\begin{tabular}{|c|c|c|c|c|c|}
\hline $\begin{array}{l}\text { Pectin/magnetite } \\
\text { coated with } \\
\text { chitosan } \\
\text { microspheres }\end{array}$ & $\begin{array}{l}\text { Ionotropic gelation } \\
\text { with } \mathrm{CaCl}_{2}\end{array}$ & $\mathrm{~N} / \mathrm{A}$ & $\begin{array}{c}\text { Diameter of } 3.05-3.69 \mathrm{~mm} \\
\text { Encapsulation efficiency of } \\
88-85 \% \\
\text { Drug loading of } 0.14-0.15 \%\end{array}$ & Metamizole & Smart drug release [96]. \\
\hline $\begin{array}{c}\text { Pectin } \\
\text { microspheres }\end{array}$ & Spray drying & $\begin{array}{l}\text { Esterification degree of } \\
62-72 \%\end{array}$ & $\begin{array}{c}\text { Encapsulation efficiency of } \\
\quad 68.4-72.2 \% \\
\text { Drug loading of } 16.6-17.0 \% \\
\text { Moisture content of } 4.37-5.59 \%\end{array}$ & Octreotide acetate & Peptide delivery [97]. \\
\hline $\begin{array}{l}\text { Pectin } \\
\text { microspheres } \\
\text { functionalized with } \\
\text { RGD peptide }\end{array}$ & $\begin{array}{l}\text { Ionotropic gelation } \\
\text { with } \mathrm{CaCl}_{2}\end{array}$ & $\begin{array}{c}\text { Esterification degree } \\
\text { of } 14 \% \\
\text { Average MW of } 29 \mathrm{kDa}\end{array}$ & $\begin{array}{c}\text { Expansion by hydration higher } \\
\text { than } 5000 \% \\
\text { Maintenance of viability, } \\
\text { proliferation, and cellular } \\
\text { differentiation until } 30 \text { days } \\
\text { 3D structures promotion for } \\
\text { cellular growth } \\
\text { Higher interaction of pinned cells } \\
\text { in the sphere with the medium }\end{array}$ & $\mathrm{N} / \mathrm{A}$ & $\begin{array}{c}\text { Immobilization } \\
\text { substrate and cellular } \\
\text { transport for tissue } \\
\text { engineering and } \\
\text { potential application in } \\
\text { regenerative medicine } \\
{[98,99] .}\end{array}$ \\
\hline $\begin{array}{l}\text { Eugradit-coated } \\
\text { pectin } \\
\text { microspheres }\end{array}$ & $\begin{array}{l}\text { W/O emulsification } \\
\text { and linking with } \mathrm{CaCl}_{2} \\
\text { + solvent evaporation }\end{array}$ & $\mathrm{N} / \mathrm{A}$ & $\begin{array}{c}\text { Diameter of } 400-600 \mu \mathrm{m} \\
\text { Yield of } 70-80 \% \\
\text { Drug (prednisolone) content of } \\
75-80 \% \\
\text { Drug (mesalamine) content of } \\
75 \% \\
\text { Expansion ratio by hydration of } \\
1.44-1.60 \\
100 \% \text { of drug release in } 14 \mathrm{~h} \text { at a } \\
\text { basic pH of } 7.4\end{array}$ & $\begin{array}{l}\text { Mesalamine + } \\
\text { Prednisolone }\end{array}$ & $\begin{array}{l}\text { Controlled drug release } \\
\text { for ulcerative colitis } \\
\text { treatment [100]. }\end{array}$ \\
\hline $\begin{array}{l}\text { Pectin/hypromellose } \\
\text { hybrid } \\
\text { microspheres }\end{array}$ & Aerosol drying & $\begin{array}{c}\text { Low methoxylated } \\
\text { amidation CF } 005 \\
\text { Esterification degree } \\
\text { of } 35 \% \\
\text { Amidation degree } \\
\text { of } 15 \%\end{array}$ & $\begin{array}{c}\text { Diameter of } 17-22 \mu \mathrm{m} \\
\text { Zeta potential of }-21 \text { to }-28 \mathrm{mV} \\
\text { Yield of } 47-65 \% \\
\text { Encapsulation efficiency of } \\
96-100 \% \\
\text { Drug content of } 25 \% \\
2-3 \% \text { of humidity } \\
80 \% \text { of fast drug release in } 120 \\
\text { min at a pH of } 6.8, \text { improving } \\
\text { drug solubility }\end{array}$ & Melatonin & $\begin{array}{l}\text { Controlled release of } \\
\text { mucoadhesive drug in } \\
\text { nasal solution [68]. }\end{array}$ \\
\hline $\begin{array}{l}\text { Pectin/sodium } \\
\text { alginate hybrid } \\
\text { microspheres }\end{array}$ & $\begin{array}{l}\text { Ionotropic gelation with } \\
\qquad \mathrm{CaCl}_{2}\end{array}$ & $\begin{array}{l}\text { Low methoxylated } \\
\text { Esterification degree } \\
\text { of } 18 \%\end{array}$ & $\begin{array}{l}\text { Diameter of } 1108-653 \mu \mathrm{m} \\
\text { Encapsulation efficiency of } \\
59-95 \% \\
90 \% \text { of fast drug release in } 6-10 \mathrm{~h} \\
\text { at a pH of } 6.8\end{array}$ & $\begin{array}{l}\text { Metformin } \\
\text { Hydrochloride }\end{array}$ & $\begin{array}{c}\text { Controlled drug release } \\
\text { for diabetes treatment } \\
\text { [101]. }\end{array}$ \\
\hline $\begin{array}{l}\text { Pectin } \\
\text { microspheres }\end{array}$ & Aerosol drying & $\mathrm{N} / \mathrm{A}$ & $\begin{array}{c}\text { Diameter of } 4.0-4.5 \mu \mathrm{m} \\
\text { Encapsulation efficiency higher } \\
\text { than } 98 \% \\
\text { Drug content of } 20-48 \% \\
\text { Yield of } 46-48 \% \\
100 \% \text { of fast drug release in } 48 \mathrm{~h} \\
\text { at a pH of } 6.4\end{array}$ & $\begin{array}{l}\text { Ciprofloxacin } \\
\text { hydrochloride }\end{array}$ & $\begin{array}{l}\text { Controlled antibiotic } \\
\text { release for osteomyelitis } \\
\text { treatment [102]. }\end{array}$ \\
\hline $\begin{array}{l}\text { Eugradit-coated } \\
\text { pectin } \\
\text { microspheres }\end{array}$ & $\begin{array}{l}\text { W/O emulsification + } \\
\text { solvent evaporation }\end{array}$ & $\mathrm{N} / \mathrm{A}$ & $\begin{array}{c}\text { Diameter of } 24-31 \mu \mathrm{m} \\
\text { Encapsulation efficiency of } \\
64-74 \% \\
\text { Expansion ratio by hydration of } \\
0.04-0.18 \\
\text { pH-dependent release; faster } \\
\text { with a basic } \mathrm{pH}(7.4) \text { and slower } \\
\text { with an acidic } \mathrm{pH}(1.2)\end{array}$ & 5-fluorouracil & $\begin{array}{l}\text { Controlled drug release } \\
\text { for colon cancer } \\
\text { treatment [103]. }\end{array}$ \\
\hline $\begin{array}{l}\text { Pectin/gellan gum } \\
\text { hybrid } \\
\text { microspheres }\end{array}$ & $\begin{array}{l}\text { Ionotropic gelation } \\
\text { with } \mathrm{AlCl}_{3}\end{array}$ & LM-5206 CS & $\begin{array}{l}\text { Average diameter of } 914 \mu \mathrm{m} \\
\text { Polydispersity index of } 0.29 \\
\text { Encapsulation efficiency of } 76 \% \\
\text { pH-dependent release: slow in an } \\
\text { acidic pH (1.2) of } 17 \% \text { in } 120 \mathrm{~min} \\
\text { and gradually controlled in a } \\
\text { basic pH }(6.8), \text { longer than } 48 \mathrm{~h} \text {. }\end{array}$ & Resveratrol & $\begin{array}{l}\text { Controlled antioxidant } \\
\text { release for colon } \\
\text { disorders } \\
\text { treatment [104]. }\end{array}$ \\
\hline $\begin{array}{l}\text { Pectin/sodium } \\
\text { alginate hybrid } \\
\text { microspheres }\end{array}$ & $\begin{array}{l}\text { Ionotropic gelation with } \\
\mathrm{CaCl}_{2}+\text { separation by } \\
\text { coacervation }\end{array}$ & $\mathrm{N} / \mathrm{A}$ & $\begin{array}{c}\text { Diameter of } 500-700 \mu \mathrm{m} \\
\text { Encapsulation efficiency of } \\
64-70 \% \\
\text { Expansion ratio by hydration of } \\
0.11-0.42 \\
\text { pH-dependent release: slow at an } \\
\text { acidic pH (1.2) of only } 8 \% \text { in } 4 \mathrm{~h} \\
\text { and maximum release at a basic } \\
\mathrm{pH}(6.8) \text { in } 12 \mathrm{~h}\end{array}$ & 5-fluorouracil & $\begin{array}{l}\text { Controlled drug release } \\
\text { for colon cancer } \\
\text { treatment [105]. }\end{array}$ \\
\hline
\end{tabular}


Table 1. Cont.

\begin{tabular}{|c|c|c|c|c|c|}
\hline $\begin{array}{l}\text { Pectin/gellan gum } \\
\text { hybrid } \\
\text { microspheres }\end{array}$ & $\begin{array}{l}\text { Ionotropic gelation with } \\
\qquad \mathrm{CaCl}_{2}\end{array}$ & $\begin{array}{c}\text { Low methoxylated and } \\
\text { amidation } \\
\text { Esterification degree of } \\
35 \%-40 \% \\
\text { Amidation degree of } \\
20 \%\end{array}$ & $\begin{array}{l}\text { Average diameter of } 250 \mu \mathrm{m} \\
\text { Encapsulation efficiency of } \\
67-88 \% \\
30-55 \% \text { of drug release at } \mathrm{pH} \text { of } \\
7.4 \text { in } 120 \mathrm{~min}\end{array}$ & Methyl violet & $\begin{array}{c}\text { Controlled drug release } \\
\text { for microorganism and } \\
\text { other human parasite } \\
\text { treatments [59]. }\end{array}$ \\
\hline $\begin{array}{l}\text { Pectin-based } \\
\text { CAP-coated } \\
\text { microspheres }\end{array}$ & Dehydration technique & $\mathrm{N} / \mathrm{A}$ & $\begin{array}{c}\text { Average diameter of } 0.8-7.06 \text { and } \\
0.9-10.31 \text { at } \mathrm{pH} 1.2, \text { whereas at } \\
\mathrm{pH} 7.4 \text {, the particle size was } \\
1.3-9.26 \text { and } 0.5-11.64 \mathrm{~mm} \text {. } \\
\text { Polydispersity index of } \\
0.245-0.267 \\
\text { Zeta potential of } 26.78-29.36 \mathrm{Mv}\end{array}$ & Mesalamine & $\begin{array}{l}\text { Controlled drug release } \\
\text { for ulcerative } \\
\text { colitis [106]. }\end{array}$ \\
\hline $\begin{array}{l}\text { Pectin } \\
\text { microspheres }\end{array}$ & $\begin{array}{l}\text { Crosslinking with } \\
\text { glutaraldehyde }+ \\
\text { Spray drying }\end{array}$ & $\mathrm{N} / \mathrm{A}$ & Sizes between 20 and $500 \mu \mathrm{m}$ & Quercetin & $\begin{array}{l}\text { Stabilization of } \\
\text { quercetin with microen- } \\
\text { capsulation [107]. }\end{array}$ \\
\hline $\begin{array}{l}\text { Eugradit-coated } \\
\text { pectin } \\
\text { microspheres }\end{array}$ & $\begin{array}{l}\text { W/O emulsification + } \\
\text { solvent evaporation }\end{array}$ & $\mathrm{N} / \mathrm{A}$ & $\begin{array}{l}\text { Diameter of } 9-14 \mu \mathrm{m} \\
\text { Encapsulation efficiency of } \\
52-75 \% \\
91-99 \% \text { of maximum drug } \\
\text { release at a pH of } 7.5 \text { in } 8 \mathrm{~h}\end{array}$ & Metronidazole & $\begin{array}{l}\text { Controlled antibiotic } \\
\text { release for colon } \\
\text { disorders } \\
\text { treatment [108]. }\end{array}$ \\
\hline
\end{tabular}

N/A = Not available.

According to Table 1, most pectin microspheres that are implemented in drug delivery applications are produced by mixing them with other polymers, obtaining hybrid spheres. A smaller percentage is represented by only pectin as a unique raw material, and the lowest percentage refers to microspheres of the pectin-coating strategy, depending on the desired final properties. The main applications are the controlled delivery/release of drugs, mostly for colon and digestive tract treatments, exerting anticancer, anti-inflammatory, and antibiotic activities. The existing information correlates with the data reported in other reviews regarding pectin as a polymer [109]. A lower percentage regards the selective treatment of illnesses such as diabetes, bone disorders, nasal drug delivery, and regenerative medicine treatments (Table 1).

Focusing on hybrid microparticles, most are reported along with negatively charged hydrophilic polymers such as alginate or gellan gum. These both provide stability [89,104], mucoadhesion to the sphere, and protection for the molecule being transported. A similar principle is targeted through coating with other compounds to increase the interaction with biological surfaces [103]. The most frequent method of synthesis consists of ionotropic gelation, which uses calcium chloride as a linking agent between other pectin types and other compounds $[94,98,99]$.

The different types of pectin shown in Table 1 exhibit varied characteristics in terms of molecular weight, esterification, and amidation degree which, combined with the synthesis method, result in particular physicochemical properties of delivery and diverse interactions, as presented in Table 1 [110]. However, they share advantages of protection, transport, and controlled drug-delivery, thus increasing treatment efficiency [111]. One of the advantages of these microspheres is that their integrity responds to $\mathrm{pH}$ variations, protecting polar and nonpolar molecules, $[65,88,93]$ and the microspheres are less sensitive to acidic $\mathrm{pH}$ of the stomach (pH 1-2) through the digestive tract. This characteristic means that they release major dosages in the guts ( $\mathrm{pH} 7.0-7.8)$, where the drug will be absorbed [10,90]. This process is critical concerning the efficient dosage of specific drugs into organs, or when an unintended release could induce adverse effects on other organs, such as in chemotherapy. This interaction revolving around $\mathrm{pH}$ can also be beneficial for drug release in nasal secretions with alkaline $\mathrm{pH}$ [65].

\subsection{Multidisciplinary Industrial Applications}

In Table 2, multiple evidence of pectin microspheres from multidisciplinary industrial applications not included in the previous section are compiled. 
Table 2. Pectin microspheres, properties, and applications in industry.

\begin{tabular}{|c|c|c|c|c|c|}
\hline Sphere Type & Synthesis Method & Pectin Properties & $\begin{array}{l}\text { Characteristics of the } \\
\text { Spheres }\end{array}$ & Field & Application \\
\hline $\begin{array}{l}\text { Pectin/alginate hybrid } \\
\text { microspheres }\end{array}$ & $\begin{array}{l}\text { Coaxial } \\
\text { electrospray system }\end{array}$ & $\mathrm{N} / \mathrm{A}$ & $\begin{array}{c}\text { Zeta potential of }-21-53 \mathrm{mV} \\
\text { Diameter of } 1.58-3.24 \mu \mathrm{m} \\
\text { Encapsulation efficiency of } \\
26-85 \%\end{array}$ & Cosmetics & $\begin{array}{c}\text { Mint essential oil } \\
\text { encapsulation for use } \\
\text { cosmetics and food [112]. }\end{array}$ \\
\hline $\begin{array}{l}\text { Pectin/jelly fig hybrid } \\
\text { microspheres }\end{array}$ & $\begin{array}{l}\text { W/O emulsification } \\
\text { and linking }+ \\
\text { reticulation with } \\
\text { formaldehyde }\end{array}$ & $\mathrm{N} / \mathrm{A}$ & $\begin{array}{c}\text { Diameter of } 58-82 \mu \mathrm{m} \\
\text { Image contrast efficiency of } \\
94 \%\end{array}$ & Electronics & $\begin{array}{l}\text { Copper phthalocyanine } \\
\text { modified by } \\
\text { cetylpyridinium chloride } \\
\text { to use it in electrophoretic } \\
\text { ink display [113]. }\end{array}$ \\
\hline $\begin{array}{l}\text { Pectin-coated } \\
\text { lanthanum oxide hybrid } \\
\text { microspheres }\end{array}$ & $\begin{array}{l}\text { Precipitation }+ \\
\text { calcination }\end{array}$ & $\mathrm{N} / \mathrm{A}$ & Diameter of $0.6-7 \mu \mathrm{m}$ & Electronics & $\begin{array}{l}\text { Lanthanum oxide sensor } \\
\text { to detect CO [114]. }\end{array}$ \\
\hline $\begin{array}{l}\text { Pectin/calcium } \\
\text { phosphate hybrid } \\
\text { microspheres }\end{array}$ & $\begin{array}{l}\text { Extrusion + linking } \\
\text { with calcium chloride }\end{array}$ & Low methoxylated & Diameter of $400-600 \mu \mathrm{m}$ & Environmental & $\begin{array}{c}\text { Promote } \\
\text { biomineralization process } \\
\text { with a biomimetic method } \\
\text { [115]. }\end{array}$ \\
\hline Pectin microspheres & $\begin{array}{l}\mathrm{pH} \text { modification }+ \\
\text { linking with calcium } \\
\text { chloride }\end{array}$ & $\begin{array}{c}\text { Galacturonic acid of }>74 \% \\
\text { Esterification degree of } \\
0.90-47 \%\end{array}$ & $\begin{array}{l}\text { Diameter of } 2 \mathrm{~mm} \\
\mathrm{~Pb} \text { (II) absorption of } 69-95 \% \\
\text { at } \mathrm{pH} 6\end{array}$ & Environmental & $\begin{array}{l}\text { Absorption of } \mathrm{Pb}(\mathrm{II}) \text { by } \\
\text { microspheres [116]. }\end{array}$ \\
\hline Pectin microspheres & Hydrothermal & $\mathrm{N} / \mathrm{A}$ & $\begin{array}{c}\text { Diameter of } 1-5 \mu \mathrm{m} \\
\text { Absorption capacity of } 905.8 \\
\mathrm{mg} / \mathrm{g} \text { at } \mathrm{t}=0.5 \mathrm{~min}\end{array}$ & Environmental & $\begin{array}{l}\text { Absorption of blue } \\
\text { methylene by } \\
\text { microspheres [72]. }\end{array}$ \\
\hline $\begin{array}{l}\text { Pectin-alginate } \\
\text { microspheres }\end{array}$ & $\begin{array}{l}\text { Ionotropic gelation } \\
\text { with } \mathrm{TiO}_{2}\end{array}$ & $\mathrm{~N} / \mathrm{A}$ & $\begin{array}{l}\text { Absorption of } 51-56 \% \text { at } \mathrm{t}= \\
30 \mathrm{~min}\end{array}$ & Environmental & $\begin{array}{c}\text { Removal of methylene } \\
\text { blue by microspheres } \\
\text { [117]. }\end{array}$ \\
\hline $\begin{array}{l}\text { Pectin/activated carbon } \\
\text { microspheres }\end{array}$ & $\begin{array}{l}\text { Ionotropic gelation } \\
\text { with } \mathrm{CaCl}_{2}\end{array}$ & $\begin{array}{c}\text { Molecular weight of } 786 \\
\mathrm{kDa} \\
\text { Degree of methoxylation } \\
\text { of } 28.3 \% \\
\text { Degree of amidation of } \\
20.63 \%\end{array}$ & Diameter of $1.30-2.78 \mathrm{~mm}$ & Environmental & $\begin{array}{l}\text { Absorption of } \mathrm{Pb}^{2+} \text { by } \\
\text { microspheres [118]. }\end{array}$ \\
\hline $\begin{array}{l}\text { Chitosan-coated pectin } \\
\text { microspheres }\end{array}$ & $\begin{array}{l}\mathrm{O} / \mathrm{W} / \mathrm{O} \\
\text { emulsification and } \\
\text { linking with } \mathrm{CaCl}_{2}\end{array}$ & Low methoxylated & $\begin{array}{c}\text { Diameter of } 100 \mu \mathrm{m} \\
\text { Bioink viscosity of } 445 \\
\mathrm{~mm}^{2 / \mathrm{s}} \\
\text { Result of assay in } \\
\text { cytotoxicity in cells } 95.7 \pm \\
1.0 \%\end{array}$ & Biotechnology & $\begin{array}{l}\text { Estradiol encapsulation } \\
\text { for use in bioprinting [46]. }\end{array}$ \\
\hline $\begin{array}{l}\text { Pectin/pea } \\
\text { protein/maltodextrin } \\
\text { hybrid microspheres }\end{array}$ & $\begin{array}{l}\text { W/O emulsification } \\
\text { and linking }\end{array}$ & $\begin{array}{l}\text { Esterification degree of } \\
60 \%\end{array}$ & $\begin{array}{c}\text { Diameter of } 0.3-400 \mu \mathrm{m} \\
\text { Encapsulation efficiency of } \\
77 \%\end{array}$ & Food & $\begin{array}{l}\text { A rich oil in } \\
\text { polyunsaturated fatty } \\
\text { acids encapsulation for } \\
\text { use in food [119]. }\end{array}$ \\
\hline $\begin{array}{l}\text { Pectin/xanthan } \\
\text { gum/wheat protein } \\
\text { hybrid microspheres }\end{array}$ & $\begin{array}{l}\text { W/O emulsification } \\
\text { and linking }\end{array}$ & $\begin{array}{l}\text { Esterification degree of }> \\
50 \% \\
\text { Average MW of } 200 \mathrm{kDa}\end{array}$ & $\begin{array}{l}\text { Zeta potential of }-9.1-23 \\
\mathrm{mV} \\
\text { Diameter of } 0.23-22 \mu \mathrm{m}\end{array}$ & Food & $\begin{array}{l}\text { Fish oil encapsulation for } \\
\text { use in food [120]. }\end{array}$ \\
\hline $\begin{array}{l}\text { Pectin/sodium alginate } \\
\text { hybrid microspheres }\end{array}$ & $\begin{array}{l}\text { W/O emulsification } \\
\text { and linking with } \\
\text { calcium chloride }\end{array}$ & $\begin{array}{c}\text { Esterification degree of }> \\
50 \%\end{array}$ & $\begin{array}{c}\text { Diameter of } 0.46-0.62 \mathrm{~mm} \\
\text { Encapsulation efficiency of } \\
52-70 \% \\
\text { Humidity content of } \\
4.29-4.73 \% \\
\text { Swelling index of } \\
0.911-0.959\end{array}$ & Food & $\begin{array}{l}\alpha \text {-tocopherol } \\
\text { encapsulation for use in } \\
\text { food [121]. }\end{array}$ \\
\hline $\begin{array}{l}\text { Pectin/maltodextrin/whey } \\
\text { protein concentrate } \\
\text { hybrid microspheres }\end{array}$ & $\begin{array}{c}\mathrm{W} / \mathrm{O} / \mathrm{W} \\
\text { emulsification }+ \\
\text { doble layer technique }\end{array}$ & $\begin{array}{c}\text { Esterification degree of } \\
71.1 \% \\
65 \% \text { galacturonic acid }\end{array}$ & $\begin{array}{c}\text { Diameter of } 0.536-0.482 \mu \mathrm{m} \\
\text { Encapsulation efficiency of } \\
93-96 \%\end{array}$ & Food & $\begin{array}{l}\text { Saffron encapsulation for } \\
\text { use in food [122]. }\end{array}$ \\
\hline $\begin{array}{l}\text { Chitosan-coated highly } \\
\text { methoxyl pectin } \\
\text { alginate hybrid } \\
\text { microspheres }\end{array}$ & $\begin{array}{l}\text { Coextrusion }+ \text { linking } \\
\text { with calcium chloride }\end{array}$ & High methoxylated & $\begin{array}{c}\text { Diameter of } 475-825 \mu \mathrm{m} \\
\text { Encapsulation efficiency of } \\
33-73 \%\end{array}$ & Food & $\begin{array}{l}\text { Kenaf seed oil } \\
\text { encapsulation for use in } \\
\text { food [123]. }\end{array}$ \\
\hline $\begin{array}{l}\text { Calcium pectinate } \\
\text { microspheres }\end{array}$ & $\begin{array}{l}\text { Ionotropic } \\
\text { gelation/Extrusion }+ \\
\text { calcium chloride } \\
\text { crosslinking }\end{array}$ & $\mathrm{N} / \mathrm{A}$ & $\begin{array}{c}\text { Encapsulation efficiency of } \\
25.2-31.1 \% \\
\text { Yield of } 92.2-97.1 \%\end{array}$ & Food & $\begin{array}{l}\text { Slow release of urea in the } \\
\text { sheep diet [124]. }\end{array}$ \\
\hline $\begin{array}{l}\text { Pectin/casein } \\
\text { microspheres }\end{array}$ & $\begin{array}{l}\text { Complex } \\
\text { coacervation }+ \text { Spray } \\
\text { drying }\end{array}$ & $\mathrm{N} / \mathrm{A}$ & $\begin{array}{c}\text { Diameter of } 4-8 \mu \mathrm{m} \\
\text { Encapsulation efficiency of } \\
60.09-83.22 \% \\
\text { Drying yield of } 3.49-18.82 \%\end{array}$ & Food & $\begin{array}{c}\text { microencapsulation of } \\
\text { phytochemicals from Vitis } \\
\text { labrusca [125]. }\end{array}$ \\
\hline
\end{tabular}


Table 2. Cont.

\begin{tabular}{|c|c|c|c|c|c|}
\hline $\begin{array}{l}\text { Pectin/Kasagumycin } \\
\text { hybrid microspheres }\end{array}$ & $\begin{array}{l}\text { Chemical linking } \\
\text { with EDC and NHS }\end{array}$ & $\begin{array}{c}\text { Esterification degree } \\
\text { of } 25 \% \\
\text { Average MW of } 70 \mathrm{kDa}\end{array}$ & $\begin{array}{c}\text { Stable a different } \mathrm{pH} \text { and } \\
\text { temperatures }\end{array}$ & Agriculture & $\begin{array}{c}\text { Kasagumycin } \\
\text { encapsulation for use } \\
\text { against crop } \\
\text { pathogens [126]. }\end{array}$ \\
\hline $\begin{array}{l}\text { Highly methoxylated } \\
\text { pectin and } \\
\text { guar-gum-coated Low } \\
\text { methoxylated } \\
\text { pectin/alginate hybrid } \\
\text { microspheres }\end{array}$ & $\begin{array}{l}\text { W/O emulsification } \\
\text { and linking with } \\
\text { calcium chloride }\end{array}$ & $\begin{array}{l}\text { Low and highly } \\
\text { methoxylated }\end{array}$ & $\begin{array}{l}\text { Number of bacteriophages } \\
\text { per microspheres } 4-6\end{array}$ & Agriculture & $\begin{array}{c}\text { Bacteriophage } \\
\text { encapsulation [127]. }\end{array}$ \\
\hline
\end{tabular}

N/A = Not available.

According to Table 2, the most cited use of pectin microspheres is the encapsulation of substances, most of which are hybrids between pectin and some other materials. This is to improve the encapsulation and subsequent delivery of the materials they contain. The different types of pectin presented multiple properties in terms of the esterification degree, molecular weight, and methoxylation degree. The synthesis methods range from emulsion (with calcium chloride as a linker) to co-extrusion; hydrothermal technology is also cited as methodology to synthesize microspheres, allowing good levels of encapsulation efficiency and subsequent delivery of the molecules.

Pectin has wide applications, from the cosmetic industry to electronics, again demonstrating the importance of microencapsulation and especially the diverse uses of pectin in disparate fields.

In the food industry, a strong growth has been demonstrated in terms of the necessary search for healthy foods [121]. For example, many of the oils that can be used in this area oxidize easily, and for these reasons, the use of encapsulation methods as protectants has potential to reduce undesirable modifications. Due to the gelling capacity of pectin, in addition to it being biocompatible, non-toxic, and digestible in the small intestine, it has been one of the most widely used products to form parts of microsphere coatings $[119,120,123]$.

The agricultural industry has also shifted to less polluting techniques, such as the use of biofertilizers or bioagents; within this topic, the controlled delivery of these agents is important for sustainable crop production [126,127]. One of the techniques for controlled release is the use of microspheres, and pectin has demonstrated good results, because it normally forms part of the cell walls in plants and is not toxic for animal consumption [126,127].

For environmental applications, the bioremediation of heavy metals is critical due to their toxicity and low biodegradability. There are different ways to treat or eliminate them, such as with chemical precipitation, flocculation, or absorption; the latter is the best option. However, it is often inefficient and expensive; thus, the technology has migrated to bioabsorption, using materials such as pectin due to its high absorption capacity and easy elimination [116]. Microencapsulation is presented as one of the most efficient technologies to perform the bioabsorption of toxic components [72]; however, despite its many environmental benefits, this field has not been explored sufficiently.

Hybrid particles can frequently be found in the presented applications because pectin microparticles retain some of the characteristics of the original polymer and, therefore, also some related limitations. The formulation of hybrid particles with other materials and chemical modification is how the properties of this material are improved. Extreme $\mathrm{pH}$ conditions produce rapid depolymerization of the pectin, frequently producing hybrid particles which enhance stability at alkaline $\mathrm{pH}$ values, and thus, greater release control [128].

Pectin microparticle applications are mainly performed under hydrophilic conditions when the particles have to be solubilized, because they generally have limited solubility in organic solvents [129].

Pectin has many properties related to its safe application in food and pharmaceuticals, with it being biocompatible and harmless; however, this also limits its use in applications as a microbial control agent, where hybrid particles with better performance have been found, such as combinations with chitosan or metals [130,131]. Pectin can be used as a 
scaffold or support in the development of biosensors and conductive material, because by itself it does not have sufficient conductive, magnetic, or bioactive capacities [132-134].

\section{Conclusions and Outlook}

According to this review, the most commonly used pectin microspheres in drug delivery and multidisciplinary industrial applications are hybrid types, combining their properties with other materials. Pectin exhibits diverse physicochemical characteristics (in terms of the esterification degree and methoxylation level), which can be manipulated through several synthesis methods aiming to maximize the properties of the microspheres for the desired applications (Tables 1 and 2). Similarly, it has been observed that these synthesis methods range from coacervation to hydrothermal techniques of precipitation or ionotropic gelation. However, the most commonly used are emulsion methods, due to their simplicity, low cost and reproducibility.

As shown by the evidence presented, microspheres have many applications, exemplified in the field of the controlled delivery of drugs, especially for the treatment of diseases of the colon and digestive tract (Table 1). Other industrial applications also share the controlled delivery of substances approach but, in this case, it is primarily focused on the protection of the encapsulated compounds, or the bioremediation of toxic substances by bioabsorption (Table 2). Nevertheless, it is also evident that more research is needed in applications with biotechnological potential, for example, in the environmental field and the agricultural industry, which could increase the use of this versatile and sustainable biomaterial. This is despite the multiple environmental benefits of pectin microspheres which have been demonstrated. This systematic review summary presents opportunities for future research in these fields.

The fact that new technologies exist, such as polymer structuring or nanotechnology, means that new solutions could be found to replace traditional options that are less effective, potentially harmful to humans and the environment, and deplete natural resources. As demonstrated through this review, the use of microspheres is beneficial for the controlled delivery of substances; moreover, they can be biocompatible and non-toxic. Pectin, especially, is reported to be an elicitor of defense responses in plants, which could possibly influence research on the use of biofertilizers or biostimulators from microspheres of this biopolymer.

Author Contributions: K.G.-A., R.C.-C. and R.S.-P. All authors contributed to writing, reviewing, and editing. All authors have read and agreed to the published version of the manuscript.

Funding: Grant ID 1510120, funded by Vice-presidency of Research and Extension at Instituto Tecnológico de Costa Rica (TEC), Cartago, Costa Rica. The authors appreciate the budget and logistical support provided by TEC.

Conflicts of Interest: The authors declare no conflict of interest.

\section{References}

1. Rampino, A.; Borgogna, M.; Bellich, B.; Blasi, P.; Virgilio, F.; Cesàro, A. Chitosan-pectin hybrid nanoparticles prepared by coating and blending techniques. Eur. J. Pharm. Sci. 2016, 84, 37-45. [CrossRef] [PubMed]

2. Mtibe, A.; Motloung, M.P.; Bandyopadhyay, J.; Ray, S.S. Synthetic Biopolymers and Their Composites: Advantages and Limitations-An Overview. Macromol. Rapid Commun. 2021, 42, 1-28. [CrossRef] [PubMed]

3. Burapapadh, K.; Takeuchi, H.; Sriamornsak, P. Development of pectin nanoparticles through mechanical homogenization for dissolution enhancement of itraconazole. Asian J. Pharm. Sci. 2016, 11, 365-375. [CrossRef]

4. Peian, Z.; Haifeng, J.; Peijie, G.; Sadeghnezhad, E.; Qianqian, P.; Tianyu, D.; Teng, L.; Huanchun, J.; Jinggui, F. Chitosan induces jasmonic acid production leading to resistance of ripened fruit against Botrytis cinerea infection. Food Chem. 2021, $337,127772$. [CrossRef] [PubMed]

5. Kolmas, J.; Krukowski, S.; Laskus, A.; Jurkitewicz, M. Synthetic hydroxyapatite in pharmaceutical applications. Ceram. Int. 2016, 42, 2472-2487. [CrossRef]

6. Szcześ, A.; Hołysz, L.; Chibowski, E. Synthesis of hydroxyapatite for biomedical applications. Adv. Colloid. Interface Sci. 2017, 249, 321-330. [CrossRef]

7. Periyasamy, K.G.K.; Zuo, H.; He, S. Flexible printed circuit board magnetic micromirror for laser marking/engraving. J. Micromech Microeng. 2019, 29, 1-11. [CrossRef] 
8. Çaykara, T.; Sande, M.G.; Azoia, N.; Rodrigues, L.R.; Silva, C.J. Exploring the potential of polyethylene terephthalate in the design of antibacterial surfaces. Med. Microbiol. Immunol. 2020, 209, 363-372. [CrossRef]

9. Rodríguez-Hernández, J.; Drummond, C. Polymer Surfaces in Motion: Unconventional Patterning Methods; Springer: Berlin/Heidelberg, Germany, 2015; Volume 1, pp. 1-289.

10. Vaidya, A.; Jain, S.; Agrawal, R.K.; Jain, S.K. Pectin-metronidazole prodrug bearing microspheres for colon targeting. J. Saudi. Chem. Soc. 2015, 19, 257-264. [CrossRef]

11. George, S.; Ho, S.S.; Wong, E.S.P.; Tan, T.T.Y.; Verma, N.K.; Aitken, R.J.; Riediker, M.; Cummings, C.; Yu, L.; Wang, Z.M.; et al. The multi-facets of sustainable nanotechnology-Lessons from a nanosafety symposium. Nanotoxicology 2015, 9, 404-406. [CrossRef]

12. Elkington, J. Triple bottom line.pdf. Environ. Qual. Manag. 1998, 8, 37-51. [CrossRef]

13. Subramanian, V.; Semenzin, E.; Hristozov, D.; Zondervan-van den Beuken, E.; Linkov, I.; Marcomini, A. Review of decision analytic tools for sustainable nanotechnology. Environ. Syst. Decis. 2015, 35, 29-41. [CrossRef]

14. Deng, L.Z.; Mujumdar, A.S.; Yang, X.H.; Wang, J.; Zhang, Q.; Zheng, Z.A.; Gao, Z.J.; Xiao, H.W. High humidity hot air impingement blanching (HHAIB) enhances drying rate and softens texture of apricot via cell wall pectin polysaccharides degradation and ultrastructure modification. Food Chem. 2018, 261, 292-300. [CrossRef]

15. Gomez, M.; Lajolo, F.; Cordenunsi, B. Evolution of soluble sugars during ripening of papaya fruit and its relation to sweet taste. J. Food Sci. 2002, 67, 442-447. [CrossRef]

16. Daher, F.B.; Braybrook, S.A. How to let go: Pectin and plant cell adhesion. Front. Plant Sci. 2015, 6, 1-8. [CrossRef]

17. Chan, S.Y.; Choo, W.S.; Young, D.J.; Loh, X.J. Pectin as a rheology modifier: Origin, structure, commercial production and rheology. Carbohydr. Polym. 2017, 161, 118-139. [CrossRef]

18. Levesque-Tremblay, G.; Pelloux, J.; Braybrook, S.A.; Müller, K. Tuning of pectin methylesterification: Consequences for cell wall biomechanics and development. Planta 2015, 242, 791-811. [CrossRef]

19. Malik, N.A.A.; Kumar, I.S.; Nadarajah, K. Elicitor and receptor molecules: Orchestrators of plant defense and immunity. Int. J. Mol. Sci. 2020, 21, 1-34.

20. Hael-Conrad, V.; Perato, S.M.; Arias, M.E.; Martínez-Zamora, M.G.; Di Peto, P.D.L.Á.; Martos, G.G.; Castagnaro, J.C.; Díaz-Ricci, J.C.; Chalfoun, N.R. The elicitor protein AsES induces a systemic acquired resistance response accompanied by systemic microbursts and micro-hypersensitive responses in Fragaria ananassa. Mol. Plant-Microbe Interact. 2018, 31, 46-60. [CrossRef]

21. Halder, M.; Sarkar, S.; Jha, S. Elicitation: A biotechnological tool for enhanced production of secondary metabolites in hairy root cultures. Eng. Life Sci. 2019, 19, 880-895. [CrossRef]

22. Selim, S.; Sanssené, J.; Rossard, S.; Courtois, J. Systemic induction of the defensin and phytoalexin pisatin pathways in pea (Pisum sativum) against aphanomyces euteiches by acetylated and nonacetylated oligogalacturonides. Molecules 2017, $22,1017$. [CrossRef] [PubMed]

23. Kirsch, R.; Vurmaz, E.; Schaefer, C.; Eberl, F.; Sporer, T.; Haeger, W.; Pauchet, Y. Plants use identical inhibitors to protect their cell wall pectin against microbes and insects. Ecol. Evol. 2020, 10, 3814-3824. [CrossRef] [PubMed]

24. Kazemi-Shahandashti, S.S.; Maali-Amiri, R. Global insights of protein responses to cold stress in plants: Signaling, defence, and degradation. J. Plant Physiol. 2018, 226, 123-135. [CrossRef] [PubMed]

25. Alba, K.; Kontogiorgos, V. Pectin at the oil-water interface: Relationship of molecular composition and structure to functionality. Food Hydrocoll. 2017, 68, 211-218. [CrossRef]

26. Avci, U.; Peña, M.J.; O’Neill, M.A. Changes in the abundance of cell wall apiogalacturonan and xylogalacturonan and conservation of rhamnogalacturonan II structure during the diversification of the Lemnoideae. Planta 2018, 247, 953-971. [CrossRef]

27. Roman, L.; Guo, M.; Terekhov, A.; Grossutti, M.; Vidal, N.P.; Reuhs, B.L.; Martinez, M.M. Extraction and isolation of pectin rich in homogalacturonan domains from two cultivars of hawthorn berry (Crataegus pinnatifida). Food Hydrocoll. 2021, 113, 106476. [CrossRef]

28. Alamgir, A.N.M. Therapeutic Use of Medicinal Plants and Their Extracts. Prog. Drug Res. 2017, 73, 105-123.

29. Xie, F.; Gu, B.J.; Saunders, S.R.; Ganjyal, G.M. High methoxyl pectin enhances the expansion characteristics of the cornstarch relative to the low methoxyl pectin. Food Hydrocoll. 2021, 110, 106131. [CrossRef]

30. Chen, J.; Liu, W.; Liu, C.M.; Li, T.; Liang, R.H.; Luo, S.J. Pectin Modifications: A Review. Crit. Rev. Food Sci. Nutr. 2015, 55, 1684-1698. [CrossRef]

31. Amsbury, S.; Hunt, L.; Elhaddad, N.; Baillie, A.; Lundgren, M.; Verhertbruggen, Y.; Scheller, H.V.; Knox, J.P.; Fleming, A.J.; Gray, J.E. Stomatal Function Requires Pectin De-methyl-esterification of the Guard Cell Wall. Curr. Biol. 2016, 26, 2899-2906. [CrossRef]

32. Krivorotova, T.; Staneviciene, R.; Luksa, J.; Serviene, E.; Sereikaite, J. Preparation and characterization of nisin-loaded pectin-inulin particles as antimicrobials. LWT-Food Sci. Technol. 2016, 72, 518-524. [CrossRef]

33. Sun, Y.; He, Y.; Wang, F.; Zhang, H.; de Vos, P.; Sun, J. Low-methoxyl lemon pectin attenuates inflammatory responses and improves intestinal barrier integrity in caerulein-induced experimental acute pancreatitis. Mol. Nutr. Food Res. 2017, 61, 1-30. [CrossRef]

34. Rose, P.A.E.; Abilasha, D. Extraction and characterization of pectin from lemon peel. Int. J. Adv. Sci. Res. 2016, 1, 12-15.

35. Hino, K.; Miyatake, S.; Yamada, F.; Endo, N.; Akiyama, R.; Ebisu, G. Undigested low-methoxy pectin prevents diarrhea and induces colonic contraction during liquid-diet feeding in rats. Nutrition 2020, 78, 110804. [CrossRef] 
36. Wu, C.; Pan, L.L.; Niu, W.; Fang, X.; Liang, W.; Li, J.; Li, H.; Pan, X.; Chen, W.; Zhang, H.; et al. Modulation of Gut Microbiota by Low Methoxyl Pectin Attenuates Type 1 Diabetes in Non-obese Diabetic Mice. Front. Immunol. 2019, 10, 1733. [CrossRef]

37. Liang, R.H.; Wang, L.H.; Chen, J.; Liu, W.; Liu, C.M. Alkylated pectin: Synthesis, characterization, viscosity and emulsifying properties. Food Hydrocoll. 2015, 50, 65-73. [CrossRef]

38. Hu, Y.; Ye, X.; Yin, X.; Chen, S. Sulfation of citrus pectin by pyridine-sulfurtrioxide complex and its anticoagulant activity. LWT-Food Sci. Technol. 2015, 60, 1162-1167. [CrossRef]

39. Tummalapalli, M.; Berthet, M.; Verrier, B.; Deopura, B.L.; Alam, M.S.; Gupta, B. Drug loaded composite oxidized pectin and gelatin networks for accelerated wound healing. Int. J. Pharm. 2016, 505, 234-245. [CrossRef]

40. Chacón-Cerdas, R.; Medaglia-Mata, A.; Flores-Mora, D.; Starbird-Pérez, R. Synthesis of chitosan, pectin, and chitosan/pectin microspheres by two water-in-oil emulsion crosslinking methods. Chem. Pap. 2020, 74, 509-520. [CrossRef]

41. Verkempinck, S.H.E.; Kyomugasho, C.; Salvia-Trujillo, L.; Denis, S.; Bourgeois, M.; Van Loey, A.M.; Hendrickx, M.E.; Grauwet, T. Emulsion stabilizing properties of citrus pectin and its interactions with conventional emulsifiers in oil-in-water emulsions. Food Hydrocoll. 2018, 85, 144-157. [CrossRef]

42. Yao, S.; Liu, H.; Yu, S.; Li, Y.; Wang, X.; Wang, L. Drug-nanoencapsulated PLGA microspheres prepared by emulsion electrospray with controlled release behavior. Regen. Biomater. 2016, 3, 309-317. [CrossRef]

43. García-González, C.A.; Jin, M.; Gerth, J.; Alvarez-Lorenzo, C.; Smirnova, I. Polysaccharide-based aerogel microspheres for oral drug delivery. Carbohydr. Polym. 2015, 117, 797-806. [CrossRef]

44. Nernplod, T.; Sriamornsak, P. Effect of solvent on properties of pectin microspheres prepared by emulsion-dehydration technique. Asian J. Pharm. Sci. 2016, 11, 217-218. [CrossRef]

45. Almeida, E.A.M.S.; Bellettini, I.C.; Garcia, F.P.; Farinácio, M.T.; Nakamura, C.V.; Rubira, A.F.; Martins, A.F.; Muniz, E. Curcuminloaded dual $\mathrm{pH}$ - and thermo-responsive magnetic microcarriers based on pectin maleate for drug delivery. Carbohydr. Polym. 2017, 171, 259-266. [CrossRef] [PubMed]

46. Johnson, D.L.; Ziemba, R.M.; Shebesta, J.H.; Lipscomb, J.C.; Wang, Y.; Wu, Y.; D O'Connell, K.; Kaltchev, M.G.; van Groningen, A.; Chen, J.; et al. Design of pectin-based bioink containing bioactive agent-loaded microspheres for bioprinting. Biomed. Phys. Eng. Express. 2019, 5, 1-27. [CrossRef]

47. Fennell, D.; Evans, H.W. The Colloidal Domain: Where Physics, Chemistry, Biology, and Technology Meet; Wiley-VCH: Weinheim, Germany, 1999; p. 672.

48. Pak, C.W.; Kosno, M.; Holehouse, A.S.; Padrick, S.B.; Mittal, A.; Ali, R.; Yunus, A.; Liu, D.R.; Pappu, R.V.; Rosen, M.K. Sequence Determinants of Intracellular Phase Separation by Complex Coacervation of a Disordered Protein. Mol. Cell 2016, 63, 72-85. [CrossRef] [PubMed]

49. Pathak, J.; Priyadarshini, E.; Rawat, K.; Bohidar, H.B. Complex coacervation in charge complementary biopolymers: Electrostatic versus surface patch binding. Adv. Colloid. Interface Sci. 2017, 250, 40-53. [CrossRef]

50. Mancer, D.; Allemann, E.; Daoud, K. Metformin hydrochloride microencapsulation by complex coacervation: Study of size distribution and encapsulation yield using response surface methodology. J. Drug Deliv. Sci. Technol. 2018, 45, 184-195. [CrossRef]

51. Villicaña-Molina, E.; Pacheco-Contreras, E.; Aguilar-Reyes, E.A.; León-Patiño, C.A. Pectin and chitosan microsphere preparation via a water/oil emulsion and solvent evaporation method for drug delivery. Int. J. Polym. Mater. Polym. Biomater. 2020, 69, 467-475. [CrossRef]

52. Noello, C.; Carvalho, A.G.S.; Silva, V.M.; Hubinger, M.D. Spray dried microparticles of chia oil using emulsion stabilized by whey protein concentrate and pectin by electrostatic deposition. Food Res. Int. 2016, 89, 549-557. [CrossRef]

53. Aloys, H.; Korma, S.; Alice, T.; Chantal, N.; Ali, A.; Abed, S.; Ildephonse, H. Microencapsulation by Complex Coacervation: Methods, Techniques, Benefits, and Applications. Am. J. Food Sci. Nutr. Res. 2016, 3, 188-192.

54. Sacco, P.; Paoletti, S.; Cok, M.; Asaro, F.; Abrami, M.; Grassi, M.; Donati, I. Insight into the ionotropic gelation of chitosan using tripolyphosphate and pyrophosphate as cross-linkers. Int. J. Biol. Macromol. 2016, 92, 476-483. [CrossRef]

55. Patel, M.A.; AbouGhaly, M.H.H.; Schryer-Praga, J.V.; Chadwick, K. The effect of ionotropic gelation residence time on alginate cross-linking and properties. Carbohydr. Polym. 2017, 155, 362-371. [CrossRef]

56. Boni, F.I.; Prezotti, F.G.; Cury, B.S.F. Gellan gum microspheres crosslinked with trivalent ion: Effect of polymer and crosslinker concentrations on drug release and mucoadhesive properties. Drug Dev. Ind. Pharm. 2016, 42, 1283-1290. [CrossRef]

57. Khoder, M.; Tsapis, N.; Huguet, H.; Besnard, M.; Gueutin, C.; Fattal, E. Removal of ciprofloxacin in simulated digestive media by activated charcoal entrapped within zinc-pectinate beads. Int. J. Pharm. 2009, 379, 251-259. [CrossRef]

58. Lascol, M.; Bourgeois, S.; Barratier, C.; Marote, P.; Lantéri, P.; Bordes, C. Development of pectin microparticles by using ionotropic gelation with chlorhexidine as cross-linking agent. Int. J. Pharm. 2018, 542, 205-212. [CrossRef]

59. Revuelta, M.V.; Villalba, M.E.C.; Navarro, A.S.; Güida, J.A.; Castro, G.R. Development of Crystal Violet encapsulation in pectin-Arabic gum gel microspheres. React. Funct. Polym. 2016, 106, 8-16. [CrossRef]

60. Belščak-Cvitanovic, A.; Bušić, A.; Barišić, L.; Vrsaljko, D.; Karlović, S.; Špoljarić, I.; Vojvodić, A.; Mršić, G.; Komes, D. Emulsion templated microencapsulation of dandelion (Taraxacum officinale L.) polyphenols and $\beta$-carotene by ionotropic gelation of alginate and pectin. Food Hydrocoll. 2016, 57, 139-152. [CrossRef]

61. Reynaud, F.; Tsapis, N.; Guterres, S.S.; Pohlmann, A.R.; Fattal, E. Pectin beads loaded with chitosan-iron microspheres for specific colonic adsorption of ciprofloxacin. J. Drug Deliv. Sci. Technol. 2015, 30, 494-500. [CrossRef] 
62. Encina, C.; Vergara, C.; Giménez, B.; Oyarzún-Ampuero, F.; Robert, P. Conventional spray-drying and future trends for the microencapsulation of fish oil. Trends Food Sci. Technol. 2016, 56, 46-60. [CrossRef]

63. Deshmukh, R.K.; Naik, J.B. Optimization of spray-dried diclofenac sodium-loaded microspheres by screening design. Dry Technol. 2016, 34, 1593-1603. [CrossRef]

64. Zaman, M.; Sajid, N.; Rehman, A.U. Gastrointestinal Mucosa: The Target Site of Mucoadhesive Microspheres, A Review. Adv. Polym. Technol. 2016, 35, 269-276. [CrossRef]

65. Jurišić Dukovski, B.; Mrak, L.; Winnicka, K.; Szekalska, M.; Juretić, M.; Filipović-Grčić, J.; Pepić, I.; Lovrić, J.; Hafner, A. Spray-dried nanoparticle-loaded pectin microspheres for dexamethasone nasal delivery. Dry Technol. 2019, 37, 1915-1925. [CrossRef]

66. García, A.; Leonardi, D.; Piccirilli, G.N.; Mamprin, M.E.; Olivieri, A.C.; Lamas, M.C. Spray drying formulation of albendazole microspheres by experimental design. In vitro-In vivo studies. Drug Dev. Ind. Pharm. 2015, 41, 244-252. [CrossRef] [PubMed]

67. Assadpour, E.; Jafari, S.-M. Spray Drying of Folic Acid within Nano-Emulsions; Optimization by Taguchi Approach. Dry Technol. 1991, 105, 135. [CrossRef]

68. Nižić, L.; Potaś, J.; Winnicka, K.; Szekalska, M.; Erak, I.; Gretić, M.; Jug, M.; Hafner, A. Development, characterisation and nasal deposition of melatonin-loaded pectin/hypromellose microspheres. Eur. J. Pharm. Sci. 2020, 141, 105115. [CrossRef] [PubMed]

69. Darr, J.A.; Zhang, J.; Makwana, N.M.; Weng, X. Continuous Hydrothermal Synthesis of Inorganic Nanoparticles: Applications and Future Directions. Chem. Rev. 2017, 117, 11125-11238. [CrossRef] [PubMed]

70. Nadimpalli, N.K.V.; Bandyopadhyaya, R.; Runkana, V. Thermodynamic analysis of hydrothermal synthesis of nanoparticles. Fluid Phase Equilib. 2018, 456, 33-45. [CrossRef]

71. Wasly, H.S.; El-Sadek, M.S.A.; Henini, M. Influence of reaction time and synthesis temperature on the physical properties of ZnO nanoparticles synthesized by the hydrothermal method. Appl. Phys. Mater. Sci. Process. 2018, 124, 124-176. [CrossRef]

72. Zhang, W.; Zhou, Z. Citrus pectin-derived carbon microspheres with superior adsorption ability for methylene blue. Nanomaterials 2017, 7, 161. [CrossRef]

73. Chauhan, N.P.S.; Gholipourmalekabadi, M.; Mozafari, M. Fabrication of newly developed pectin-GeO $\mathrm{O}_{2}$ nanocomposite using extreme biomimetics route and its antibacterial activities. J. Macromol. Sci. Part A Pure Appl. Chem. 2017, 54, 655-661. [CrossRef]

74. Atchudan, R.; Jebakumar Immanuel Edison, T.N.; Shanmugam, M.; Perumal, S.; Somanathan, T.; Lee, Y.R. Sustainable synthesis of carbon quantum dots from banana peel waste using hydrothermal process for in vivo bioimaging. Phys. E Low-Dimens. Syst. Nanostructures 2021, 126, 114417. [CrossRef]

75. Chew, S.C.; Nyam, K.L. Microencapsulation of kenaf seed oil by co-extrusion technology. J. Food Eng. 2016, 175, 43-50. [CrossRef]

76. Vallejo-Castillo, V.; Rodríguez-Stouvenel, A.; Martínez, R.; Bernal, C. Development of alginate-pectin microcapsules by the extrusion for encapsulation and controlled release of polyphenols from papaya (Carica papaya L.). J. Food Biochem. 2020, 44, 1-17. [CrossRef]

77. Leong, M.H.; Tan, C.P.; Nyam, K.L. Effects of Accelerated Storage on the Quality of Kenaf Seed Oil in Chitosan-Coated High Methoxyl Pectin-Alginate Microcapsules. J. Food Sci. 2016, 81, C2367-C2372. [CrossRef]

78. Silva, M.P.; Tulini, F.L.; Martins, E.; Penning, M.; Fávaro-Trindade, C.S.; Poncelet, D. Comparison of extrusion and co-extrusion encapsulation techniques to protect Lactobacillus acidophilus LA3 in simulated gastrointestinal fluids. LWT-Food Sci. Technol. 2018, 89, 392-399. [CrossRef]

79. Muley, S.; Nandgude, T.; Poddar, S. Extrusion-spheronization a promising pelletization technique: In-depth review. Asian J. Pharm. Sci. 2016, 11, 684-699. [CrossRef]

80. Martins, A.L.L.; de Oliveira, A.C.; do Nascimento, C.M.O.L.; Silva, L.A.D.; Gaeti, M.P.N.; Lima, E.M.; Taveira, S.; Fernandes, K.; Marreto, R. Mucoadhesive Properties of Thiolated Pectin-Based Pellets Prepared by Extrusion-Spheronization Technique. J. Pharm. Sci. 2017, 106, 1363-1370. [CrossRef]

81. Pinc, J.; Čapek, J.; Hybášek, V.; Průša, F.; Hosová, K.; Maňák, J.; Vojtech, D. Characterization of newly developed zinc composite with the content of $8 \mathrm{wt}$. \% of hydroxyapatite particles processed by extrusion. Materials 2020, 13, 1716. [CrossRef]

82. Kiaei Pour, P.; Alemzadeh, I.; Vaziri, A.S.; Beiroti, A. Potential effects of alginate-pectin biocomposite on the release of folic acid and their physicochemical characteristics. J. Food Sci. Technol. 2020, 57, 3363-3370. [CrossRef]

83. Rehman, A.; Ahmad, T.; Aadil, R.M.; Spotti, M.J.; Bakry, A.M.; Khan, I.M.; Zhao, L.; Riaz, T.; Tong, Q. Pectin polymers as wall materials for the nano-encapsulation of bioactive compounds. Trends Food Sci. Technol. 2019, 90, 35-46. [CrossRef]

84. Ahirwar, D.; Ahirwar, B.; Anish, C. Microspheres for Targeting an Alkaloidal Anticancer Drug in Colon Cancer. Res. J. Pharm. Technol. 2013, 6, 618-621.

85. Banerjee, P.; Deb, J.; Roy, A.; Ghosh, A.; Chakraborty, P. Fabrication and Development of Pectin Microsphere of Metformin Hydrochloride. ISRN Pharm. 2012, 2012, 1-7. [CrossRef] [PubMed]

86. Bayón, B.; Bucalá, V.; Castro, G.R. Development of antimicrobial hybrid mesoporous silver phosphate-pectin microspheres for control release of levofloxacin. Microporous Mesoporous Mater. 2016, 226, 71-78. [CrossRef]

87. Bourgeois, S.; Laham, A.; Besnard, M.; Andremont, A.; Fattal, E. In vitro and in vivo evaluation of pectin beads for the colon delivery of $\beta$-lactamases. J. Drug Target. 2005, 13, 277-284. [CrossRef]

88. Bigucci, F.; Luppi, B.; Monaco, L.; Cerchiara, T.; Zecchi, V. Pectin-based microspheres for colon-specific delivery of vancomycin. J. Pharm. Pharmacol. 2008, 61, 41-46. [CrossRef] 
89. Chakraborty, S.; Khandai, M.; Sharma, A.; Khanam, N.; Patra, C.; Dinda, S.; Sen, K. Preparation, in vitro and in vivo evaluation of algino-pectinate bioadhesive microspheres: An investigation of the effects of polymers using multiple comparison analysis. Acta Pharm. 2010, 60, 255-266. [CrossRef]

90. Chaurasia, M.; Chourasia, M.; Jain, N.; Jain, A.; Soni, V.; Gupta, Y.; Jain, S.K. Methotrexate Bearing Calcium Pectinate Microspheres: A Platform to Achieve Colon-Specific Drug Release. Curr. Drug Deliv. 2008, 5, 215-219. [CrossRef]

91. Da Silva, E.P.; Sitta, D.L.A.; Fragal, V.H.; Cellet, T.S.P.; Mauricio, M.R.; Garcia, F.P.; Nakamura, C.V.; Guilherme, M.R.; Rubira, A.F.; Kunita, M.H. Covalent $\mathrm{TiO}_{2}$ /pectin microspheres with $\mathrm{Fe}_{3} \mathrm{O}_{4}$ nanoparticles for magnetic field-modulated drug delivery. Int. J. Biol. Macromol. 2014, 67, 43-52. [CrossRef]

92. Das, S.; Ng, K.Y.; Ho, P.C. Design of a pectin-based microparticle formulation using zinc ions as the cross-linking agent and glutaraldehyde as the hardening agent for colonic-specific delivery of resveratrol: In vitro and in vivo evaluations. J. Drug Target. 2011, 19, 446-457. [CrossRef]

93. Fullana, S.G.; Ternet, H.; Freche, M.; Lacout, J.L.; Rodriguez, F. Controlled release properties and final macroporosity of a pectin microspheres-calcium phosphate composite bone cement. Acta Biomater. 2010, 6, 2294-2300. [CrossRef]

94. Islan, G.A.; De Verti, I.P.; Marchetti, S.G.; Castro, G.R. Studies of ciprofloxacin encapsulation on alginate/pectin matrixes and its relationship with biodisponibility. Appl. Biochem. Biotechnol. 2012, 167, 1408-1420. [CrossRef]

95. Lee, C.M.; Kim, D.W.; Lee, H.C.; Lee, K.Y. Pectin microspheres for oral colon delivery: Preparation using spray drying method and in vitro release of indomethacin. Biotechnol. Bioprocess. Eng. 2004, 9, 191-195. [CrossRef]

96. Lemos, T.S.A.; Souza, J.F.; De Fajardo, R. Magnetic microspheres based on pectin coated by chitosan towards smart drug release. Carbohydr. Polym. 2021, 265, 1-10. [CrossRef]

97. Li, T.; Wan, B.; Jog, R.; Costa, A.; Burgess, D.J. Pectin microparticles for peptide delivery: Optimization of spray drying processing. Int. J. Pharm. 2022, 613, 121384. [CrossRef]

98. Munarin, F.; Guerreiro, S.G.; Grellier, M.A.; Tanzi, M.C.; Barbosa, M.A.; Petrini, P.; Granja, P.L. Pectin-based injectable biomaterials for bone tissue engineering. Biomacromolecules 2011, 12, 568-577. [CrossRef]

99. Munarin, F.; Petrini, P.; Tanzi, M.C.; Barbosa, M.A.; Granja, P.L. Biofunctional chemically modified pectin for cell delivery. Soft Matter. 2012, 8, 4731-4739. [CrossRef]

100. Jain Singhai, N.; Rawal, A.; Maurya, R.; Ramteke, S. Design and Characterization of Dual Drug Loaded Microspheres for Colon. J. Drug Deliv. Ther. 2019, 9, 12-22.

101. Okunlola, A.; Akindele, O. Application of Response Surface Methodology and Central Composite Design for the Optimization of Metformin Microsphere Formulation using Tangerine (Citrus tangerina) Pectin as Copolymer. Br. J. Pharm. Res. 2016, 11, 1-14. [CrossRef]

102. Orhan, Z.; Cevher, E.; Mülazimoglu, L.; Gürcan, D.; Alper, M.; Araman, A.; Ozsoy, Y. The preparation of ciprofloxacin hydrochloride-loaded chitosan and pectin microspheres. Their evaluation in an animal osteomyelitis model. J. Bone Jt. Surg. Ser. B 2006, 88, 270-275. [CrossRef]

103. Paharia, A.; Yadav, A.K.; Rai, G.; Jain, S.K.; Pancholi, S.S.; Agrawal, G.P. Eudragit-coated pectin microspheres of 5-Fluorouracil for colon targeting. AAPS PharmSciTech 2007, 8, 87-93. [CrossRef]

104. Prezotti, F.G.; Boni, F.I.; Ferreira, N.N.; de Souza e Silva, D.; Campana-Filho, S.P.; Almeida, A.; Vasconcelos, T.; Daflon, M.P.; Ferreira, B.S.; Sarmento, B. Gellan gum/pectin beads are safe and efficient for the targeted colonic delivery of resveratrol. Polymers 2018, 10, 50. [CrossRef]

105. Ramana, G.; Krishna Chaitanya, A. Preparation and In-vitro characterization of ethylcellulose coated pectin alginate microspheres of 5-fluorouracil for colon targeting. J. Appl. Pharm. Sci. 2011, 1, 170-176.

106. Singh, A.; Mandal, U.K.; Narang, R.K. Development and In Vivo Evaluation of Pectin Based Enteric Coated Microparticles Loaded with Mesalamine and Saccharomyces boulardii for Management of Ulcerative Colitis. Assay Drug Dev. Technol. 2022, 20, 22-34. [CrossRef] [PubMed]

107. Souza, K.; Moreira, L.; Silva, B.T.; Oliveira, B.P.; Carvalho, A.S.; Silva, P.S.; Verri, W.A., Jr.; Sá-Nakanishi, A.B.; Bracht, L.; Zanoni, J.N.; et al. Low dose of quercetin-loaded pectin/casein microparticles reduces the oxidative stress in arthritic rats. Life Sci. 2021, 284, 119910. [CrossRef]

108. Vaidya, A.; Jain, A.; Khare, P.; Agrawal, R.; Jain, S. Metronidazole Loaded Pectin Microspheres for Colon Targeting. J. Pharm. Sci. 2009, 98, 4229-4236. [CrossRef]

109. Shukla, S.; Verma, K.; Jain, D.; Verma, S. Pectin-based colon-specific drug delivery. Chronicles Young Sci. 2011, 2, 83. [CrossRef]

110. Reddy, N.; Reddy, R.; Jiang, Q. Crosslinking biopolymers for biomedical applications. Trends Biotechnol. $2015,33,362-369$. [CrossRef] [PubMed]

111. Singh, M.N.; Hemant, K.S.Y.; Ram, M.; Shivakumar, H.G. Microencapsulation: A promising technique for controlled drug delivery. Res. Pharm. Sci. 2010, 5, 65-77. [PubMed]

112. Koo, S.Y.; Cha, K.H.; Song, D.G.; Chung, D.; Pan, C.H. Microencapsulation of peppermint oil in an alginate-pectin matrix using a coaxial electrospray system. Int. J. Food Sci. Technol. 2014, 49, 733-739. [CrossRef]

113. Chou, W.-M.; Wang, L.-L.; Yu, H.H. Electrophoretic Ink Display Prepared by Jelly Fig Pectin/Gelatin Microspheres. Smart Sci. 2015, 3, 74-79. [CrossRef]

114. Michel, C.R.; Martínez-Preciado, A.H. CO sensing properties of novel nanostructured $\mathrm{La}_{2} \mathrm{O}_{3}$ microspheres. Sens. Actuators $B$ Chem. 2015, 208, 355-362. [CrossRef] 
115. Munarin, F.; Giuliano, L.; Bozzini, S.; Tanzi, M.C.; Petrini, P. Mineral phase deposition on pectin microspheres. Mater. Sci. Eng. C 2010, 30, 491-496. [CrossRef]

116. Li, F.; Xu, Z.; Wen, X.; Li, X.; Bai, Y.; Li, J. Preparation and characterization of Ca(II) cross-linking modified pectin microspheres for $\mathrm{Pb}(\mathrm{II})$ adsorption. Water Sci. Technol. 2019, 79, 1484-1493. [CrossRef]

117. Zamri, N.I.I.; Zulmajdi, S.L.N.; Daud, N.Z.A.; Mahadi, A.H.; Kusrini, E.; Usman, A. Insight into the adsorption kinetics, mechanism, and thermodynamics of methylene blue from aqueous solution onto pectin-alginate-titania composite microparticles. SN Appl. Sci. 2021, 3, 1-16. [CrossRef]

118. Wang, R.; Li, Y.; Shuai, X.; Liang, R.; Chen, J.; Liu, C. Pectin/Activated Carbon-Based Porous Microsphere for Pb ${ }^{2+}$ Adsorption: Characterization and Adsorption Behaviour. Polymers 2021, 13, 1-7.

119. Aberkane, L.; Roudaut, G.; Saurel, R. Encapsulation and Oxidative Stability of PUFA-Rich Oil Microencapsulated by Spray Drying Using Pea Protein and Pectin. Food Bioprocess. Technol. 2014, 7, 1505-1517. [CrossRef]

120. Qiu, C.; Zhao, M.; Decker, E.A.; McClements, D.J. Influence of anionic dietary fibers (xanthan gum and pectin) on oxidative stability and lipid digestibility of wheat protein-stabilized fish oil-in-water emulsion. Food Res. Int. 2015, 74, 131-139. [CrossRef]

121. Singh, J.; Kaur, K.; Kumar, P. Optimizing microencapsulation of $\alpha$-tocopherol with pectin and sodium alginate. J. Food Sci. Technol. 2018, 55, 3625-3631. [CrossRef]

122. Esfanjani, A.F.; Jafari, S.M.; Assadpoor, E.; Mohammadi, A. Nano-encapsulation of saffron extract through double-layered multiple emulsions of pectin and whey protein concentrate. J. Food Eng. 2015, 165, 149-155. [CrossRef]

123. Chew, S.C.; Tan, C.P.; Long, K.; Nyam, K.L. In-vitro evaluation of kenaf seed oil in chitosan coated-high methoxyl pectin-alginate microcapsules. Ind. Crops Prod. 2015, 76, 230-236. [CrossRef]

124. Melo, M.; da Silva, A.; Filho, E.S.; Oliveira, R.; Junior, J.S.; Oliveira, J.P.; Vaz, A.; Moura, J.; Pererira, J.; Bezerra, L. Polymeric microparticles of calcium pectinate containing urea for slow release in ruminant diet. Polymers 2021, 13, 3776. [CrossRef] [PubMed]

125. Carra, J.B.; Matos, R.L.N.; de Novelli, A.P.; Couto, R.O.; do Yamashita, F.; Ribeiro, M.A.; dos Santos Ribeiro, M.A.; Meurer, E.C.; Junior, W.A.V.; Casagrande, R.; et al. Spray-drying of casein/pectin bioconjugate microcapsules containing grape (Vitis labrusca) by-product extract. Food Chem. 2022, 368, 1-10. [CrossRef] [PubMed]

126. Liu, Y.; Sun, Y.; Ding, G.; Geng, Q.; Zhu, J.; Guo, M.; Duan, Y.; Wang, B.; Cao, Y. Synthesis, characterization, and application of microbe-triggered controlled-release kasugamycin-pectin conjugate. J. Agric. Food Chem. 2015, 63, 4263-4268. [CrossRef] [PubMed]

127. Dini, C.; Islan, G.A.; de Urraza, P.J.; Castro, G.R. Novel biopolymer matrices for microencapsulation of phages: Enhanced protection against acidity and protease activity. Macromol. Biosci. 2012, 12, 1200-1208. [CrossRef] [PubMed]

128. Guo, J.; Kaletunç, G. Dissolution kinetics of pH responsive alginate-pectin hydrogel particles. Food Res. Int. 2016, 88, 129-139. [CrossRef]

129. Bhatia, M.S.; Choudhari, P.; Bhatia, N.M.; Deshmukh, R. Chemical modification of pectins, characterization and evaluation for drug delivery. Sci. Pharm. 2008, 76, 775-784. [CrossRef]

130. Lara-Espinoza, C.; Carvajal-Millán, E.; Balandrán-Quintana, R.; López-Franco, Y.; Rascón-Chu, A. Pectin and pectin-based composite materials: Beyond food texture. Molecules 2018, 23, 942. [CrossRef]

131. Akalin, G.O.; Oztuna Taner, O.; Taner, T. The preparation, characterization and antibacterial properties of chitosan/pectin silver nanoparticle films. Polym. Bull. 2021, 0123456789, 1-18. [CrossRef]

132. Nemiwal, M.; Zhang, T.C.; Kumar, D. Pectin modified metal nanoparticles and their application in property modification of biosensors. Carbohydr. Polym. Technol. Appl. 2021, 2, 100164. [CrossRef]

133. Dolinska, J.; Holdynski, M.; Pieta, P.; Lisowski, W.; Ratajczyk, T.; Palys, B.; Jablonska, A.; Opallo, M. Noble metal nanoparticles in pectin matrix. Preparation, film formation, property analysis, and application in electrocatalysis. ACS Omega. 2020, 5, 23909-23918. [CrossRef]

134. Dai, J.; Wu, S.; Jiang, W.; Li, P.; Chen, X.; Liu, L.; Liu, J.; Sun, D.; Chen, W.; Chen, B.; et al. Facile synthesis of pectin coated Fe3O4 nanospheres by the sonochemical method. J. Magn. Magn. Mater. 2013, 331, 62-66. [CrossRef] 